University of Windsor

Scholarship at UWindsor

6-2007

\title{
An Entrepreneur and a Leader!: A Framework Conceptualizing the Influence of Leadership Style on a Firm's Entrepreneurial Orientation-- Performance Relationship
}

\author{
Francine K. Schlosser \\ Odette School of Business, University of Windsor \\ Zelimir William Todorovic
}

Follow this and additional works at: https://scholar.uwindsor.ca/odettepub

Part of the Business Commons

\section{Recommended Citation}

Schlosser, Francine K. and Todorovic, Zelimir William. (2007). An Entrepreneur and a Leader!: A Framework Conceptualizing the Influence of Leadership Style on a Firm's Entrepreneurial Orientation-Performance Relationship. Journal of Small Business and Entrepreneurship, 20 (3).

https://scholar.uwindsor.ca/odettepub/114

This Article is brought to you for free and open access by the Odette School of Business at Scholarship at UWindsor. It has been accepted for inclusion in Odette School of Business Publications by an authorized administrator of Scholarship at UWindsor. For more information, please contact scholarship@uwindsor.ca. 


\title{
An Entrepreneur and a Leader!
}

\author{
A Framework Conceptualizing the Influence of Leadership Style on a Firm's \\ Entrepreneurial Orientation - Performance Relationship ${ }^{\bullet}$
}

\author{
Želimir William Todorović \\ Indiana-Purdue University \\ Fort Wayne, Indiana
}

\author{
Francine K. Schlosser \\ University of Windsor \\ Windsor, Canada
}

CITATION: Todorovic, Z. W. and Schlosser, F.K. (2007). An Entrepreneur and a Leader! A Framework Conceptualizing the Influence of Leader Style on a Firm's Entrepreneurial Orientation-Performance Relationship. Journal of Small Business and Entrepreneurship 20(3), 289-308.

\section{Correspondence to:}

Bill Todorovic

Department of Management and Marketing

Indiana - Purdue University, Fort Wayne

2101 E. Coliseum Blvd.

Fort Wayne, Indiana, 46805-1499

Email: todorovz@ipfw.edu

Dr. Bill Todorovic is the Director of Entrepreneurship Certificate Program at Indiana-Purdue University in Fort Wayne. His research interests include the fostering of entrepreneurial orientation in the public sector as well as in cross cultural framework. Dr. Francine Schlosser is an Assistant Professor of Management in the Odette School of Business at the University of Windsor. She is currently researching entrepreneurial and knowledge management behaviours of employees and employers.

Key Words: $\quad$ entrepreneur, entrepreneurial orientation, machiavellian, charisma, leadership

\footnotetext{
- A previous version of this paper won an honorable mention award from the Centre for Creative Leadership, Greensboro, North Carolina, December, 2002 and was also accepted for presentation at the Academy of Management Seattle Conference 2003. We would like to acknowledge the insightful comments provided by two anonymous reviewers for the 2003 Academy of Management Meeting, Seattle.
} 


\begin{abstract}
Previous research has demonstrated a relationship between entrepreneurial orientation (EO) and organizational performance. Utilizing the resource based view theoretical paradigm, past empirical and theoretical research is synthesized towards a common conceptual framework which examines the role of charismatic leadership in the EO-Performance relationship. Incorporating previous leadership research on charisma and machiavellianism, it is proposed that either egocentric (self-enhancing) or collective (organizational) values of the individuals working at the organization will influence the EO-performance relationship. This paper asserts that a charismatic leader will stimulate positive employee organizational citizenship behaviour, whereas machiavellian leader will stimulate negative employee impression management practices. Understanding the role leadership plays in today's environment, entrepreneurs will be better able to equip their human resource to achieve their vision of tomorrow.
\end{abstract}

\title{
Introduction
}

As the world economic environment grows more dynamic, changing at an accelerated rate, today's companies must become more flexible, adaptive, and entrepreneurial. Subsequently, a number of studies examined the role that Entrepreneurial Orientation (with its dimensions on innovation, risk-taking and proactiveness) plays in preparing today's companies for global competition. Further, many of these studies indicate a correlation between EO and organizational performance across different firms (for example, Smart \& Conant, 1994; Zahra, 1991). Other studies found that this relationship is strengthened within environments of increased hostility (for example, Becherer \& Maurer, 1997; Covin \& Slevin, 1989; Zahra, 1991). This suggests that EO makes organizations more flexible, allowing them to achieve competitive advantage. In fact, EO as a source of competitive advantage was previously been examined as a part of the Resource Based View (Alvarez \& Busenitz, 2001; Amit \& Schoemaker, 1993; Peteraf, 1994). The aim of this paper is to expand the horizon by contributing to better understanding of the role leadership plays in the EO-Performance relationship. A conceptual framework is proposed that incorporates entrepreneur's leadership style, and follower behaviour into the EO-Performance relationship. 
Very little work exists that examines the role leadership plays in the EO-Performance relationship. Although the link between entrepreneurial orientation and performance outcomes has previously been demonstrated (for example, Smart \& Conant, 1994; Zahra, 1991), this relationship appears to vary in magnitude between different firms (Lumpkin \& Dess, 2001; Zahra, Covin, \& Slevin, 1995) . Such a variance may indicate the presence of variables not accounted for in previous research. For example firms in hostile environments benefit significantly from being entrepreneurially oriented, thereby amplifying the effect.

Further, this paper proposes that perceptions of entrepreneur charisma and machiavellianism are related to various organizational and employee outcomes, such as venture success and workplace behaviours (Awamleh \& Gardner, 1999). Based on prior research, this paper presents a conceptual framework that elaborates on the role charismatic (or Machivellian) leadership style has on the EO-Performance relationship. In due process of analysis, a realization has also been attained that the specific leadership style also impacts follower response, further amplifying the overall effect. The proposed conceptual framework suggests that entrepreneur leadership plays a pivotal role through both directly, as well as through the amplified effect of the follower response.

Finally, this paper also combines individual level and organizational level literature in an effort to find a more comprehensive conceptual framework. Noting that EO-performance relationship has been examined at the organizational level of analysis (for example, Becherer \& Maurer, 1997; Miller \& Friesen, 1982; Naman \& Slevin, 1993; Wiklund, 1999; Zahra et al., 1995), there is insufficient examination addressing the variability of the EO-performance relationship from the vantage of individual level analysis. Incorporating research from leadership 
literature, this paper develops a theoretical argument that examines the behaviours of managers and employees, and their effects on the organizational EO-Performance relationship.

When examining the impact of leadership on entrepreneurial success, success is defined as a firm's ability to succeed and grow. Such a definition suggests that evaluation other than financial measures must be included in the assessment of performance. This definition is consistent with previously used observations (Allen \& McCluskey, 1990; Becherer \& Maurer, 1997; Feeser \& Willard, 1989). This paper contends that these variables include characteristics of the managers and of their employees. Thus, the focus of this theoretical argument will surround how the influence of entrepreneurial orientation on performance may be affected by characteristics of business leaders and employees.

This discussion, which represents a sharing of knowledge between leadership and behavioural theories, and entrepreneurship and entrepreneurial orientation viewpoints, proceeds as follows. First, literature on Entrepreneurial Orientation, and related theoretical basis is reviewed. A discussion of previous research on leader charisma, machiavellianism, employee organizational citizenship behaviour, and impression management ensues. A framework is developed explaining the moderating role of managerial leadership styles and employee outcomes on the EO-Performance relationship. Finally, directions for future research are proposed.

\section{Understanding Entrepreneurial Orientation}

The study of EO has its roots in the field of strategy research (Child, 1972; Miles \& Snow, 1978; Mintzberg, 1973). Although there is no clear consensus in literature on what constitutes entrepreneurship, EO is a more clearly defined concept. Miller defined an 
entrepreneurial firm as one that "engages in product marketing innovation, undertakes somewhat risky ventures, and is first to come up with proactive innovations" (Miller, 1983: 771). Furthermore, Morris and Paul (1987) described entrepreneurial orientation as the inclination of top management to take calculated risks, to be innovative and to demonstrate proactiveness. However, for the purposes of this paper, EO is defined as entrepreneurship at the organizational level (Lee, Lee, \& Pennings, 2001).

In addition to being defined as organizational level entrepreneurship, it has been recognized that EO is a multi-dimensional construct. Miller (1983) operationalized the EO construct to include innovation, risk-taking and proactiveness. This definition has been the base for several subsequent studies (for example, Covin \& Slevin, 1989; Lumpkin \& Dess, 2001; Wiklund, 1999). Additionally, Lumkin and Dess (1996) have considered two more dimensions to EO: competitive aggressiveness and autonomy. As the rate of change in global environment increases, and business leaders attempt to make their companies more entrepreneurial, understanding EO becomes a crucial tool towards improving firm performance.

Past researchers have recognized the importance of EO because of its positive relationship with organizational performance. Covin and Slevin (1986) found a statistically significant correlation of .39 between EO and firm performance. Such a relationship has been replicated by other studies (Smart \& Conant, 1994; Zahra, 1991).

Miller and Friesen (1978) found that firms operating in highly hostile environments are more competitive if they have higher amount of entrepreneurial orientation. Consequently, environmental hostility has been included as a moderating variable in the EO-performance relationship for firms of all sizes (Zahra, 1993; Zahra et al., 1995). For example, Khandwalla (1977), who developed items that served as a base for EO scale, observed that the entrepreneurial 
style is more effective for smaller firms in hostile environments. Guth and Ginsberg (1990) have also observed that EO is a crucial approach to continued growth and strategic renewal in a hostile business environment. Accordingly, the positive effect of EO on organizational performance (especially within the dynamic and hostile environments currently faced by many firms) is the basis of the theoretical arguments made in this paper.

\section{Entrepreneurial Orientation and the Theoretical Context}

Studies of Entrepreneurial Orientation (EO) have linked it to Resource Based View (RBV) (for example, Alvarez \& Busenitz, 2001; Lee et al., 2001). Resource Based View (RBV), also referred to as the Resource Based Theory, was first advocated by Penrose (1959), in her book "The Theory of the Growth of the Firm". The main purpose of the RBV framework is to enhance an understanding of how competitive advantage within firms is achieved and how that advantage might be sustained in the future (Barney, 1991; Eisenhardt \& Martin, 2000; Nelson, 1991; Penrose, 1959; Schumpeter, 1934; Teece, Pisano, \& Shuen, 1997; Wernerfelt, 1984).

With its roots in the literature of strategic management, EO represents a search for additional rents under RBV. Entrepreneurial orientation is seen as an internal organizational capability, allowing for innovativeness, risk-taking and proactiveness (Lee et al., 2001). More specifically, the organization is able to continuously re-adjust its capabilities (that is be innovative, take risks, be proactive). As a result, EO can be viewed as a dynamic capability within the RBV framework (Eisenhardt \& Martin, 2000). According to Teece et al., these dynamic capabilities are crucial in enabling "wealth creation and capture by private enterprise firms operating in environments of rapid change" (1997: 509). Consequently, these 
entrepreneurial actions combine to create new heterogeneous resources, therefore leading to competitive advantage (Alvarez \& Busenitz, 2001).

Changes in the external environment are accompanied by a heightened emphasis on "invisible" assets (Itami \& Roehl, 1987). As the speed of technological expansion increases on a global scale, firms start to rely more heavily on their internal advantages (Teece et al., 1997). These resources provide the firms with "rent" or return, potentially leading to competitive advantage for the firm. As firms are considered to be bundles of heterogeneous resources, these resources have varying impacts on competitive advantage (Alvarez \& Busenitz, 2001; Eisenhardt \& Martin, 2000).

The leadership and decision-making styles of management represent valuable resources (Cyert \& March, 1963, 1992). Charismatic leadership, as in this case of the entrepreneur, is an individual level trait (House, 1977 For example, "Charismatic leadership is an attribution based on followers' perception of their leader's behavior" (Conger 1999, p. 153). An entrepreneur, the individual, is often cross-identified with the organization itself. To explain, the entrepreneur's vision may quickly become the organization's vision statement. Charismatic leadership of the entrepreneur can also be viewed as being a (or leading to an) organizational level resource, therefore contributing to firm performance. Likewise, a Machiavellian leadership style may also have a negative effect on organizational resources of the organization. In other words, appropriate leadership style may enable the firm to achieve outcomes not possible otherwise. It follows therefore that an appropriate leadership style can be seen as a resource under RBV. 


\section{Discussion of Performance}

Although this paper presents a conceptual framework, it is important to discuss and define the concept of performance. Although the studies on EO are fairly consistent in demonstrating the relationship between EO and organizational performance, the definition of organizational performance itself is by no means a simple task. In their study, Covin and Slevin (1989) used financial measures (sales, cash flow, ROI) to evaluate firm performance. Although the use of financial measures is very common, it has come under significant criticism, especially as it pertains to entrepreneurial businesses (Reid \& Smith, 2000). It can be observed, however, that a charismatic leader, a leader that is vision driven, may not be nearly concerned with providing sufficient dividends to the shareholder, as she or he may be about building the company, following a vision, and achieving objectives. In recognition of this some authors used non-financial aspects to measure performance. For example Smart and Conant (1994) used distinctive marketing competency in addition to organizational performance. Hansen and Wernerfelt (1989) used more perceptual measures (economic and organizational), while Williamson (1999) used a combination of financial and growth measures. Although any one of these measures may be useful in different situations, a combination of financial and growth measures, such as were used by Williamson (1999), are likely to be most useful for the purposes of the discussion of the proposed framework. That is, growth and performance measures may be closest to the emphasis of entrepreneurs, who are likely to be more concerned with growing their company, then they are about appeasing shareholders or directors (Bygrave \& Minniti, 2000). Therefore, for the purposes of the discussion of this framework, performance that consists of a combination of financial and growth measures (as used by Williamson 1999 for example) is most appropriate. 


\section{Development of a Proposed Framework}

This discussion focuses upon the development of a framework and ensuing propositions surrounding the influence of individual managers and employees on the EO-performance relationship. We propose that the EO-performance relationship will be influenced by either egocentric (self-enhancing) or collective (organizational) values of the individuals working at the organization. Avolio and Locke (2002) previously described the effect different leadership styles have on the organization, supporting the basic premise of the above proposition. Hence, the present argument builds upon past research, and specifically upon an understanding of entrepreneurial orientation as it relates to organizational performance. Figure 1 summarizes the overall conceptual framework that guides this discussion.

\section{INSERT: Figure 1- A Conceptual Framework of Leader - Follower Relationship}

\section{Introduction to the Framework}

For the purposes of discussion, the effect of motives on leadership on follower behaviour is presented on two axes. The X-Axis shows the value system of the leader (that is, motive) as perceived by the employee. In this paper, the value system is defined as the underlying motive, which can range from "Collective" on one end of the axis to "Egocentric" on the other. The Yaxis shows the degree of intensity of actions - in terms of leader (positive y-axis) and follower (negative $\mathrm{y}$-axis). In essence, the $\mathrm{Y}$-axis recognizes that there are different intensities of actions engaged by the leaders. Intensity is hereby defined as the degree of charismatic (or machiavellian) behaviour as well as the frequency of occurrences of the expression of the same 
(that is, regularity of contact between the leaders and the follower). For example, it is asserted that a strong collective influence frequently represented by a charismatic leader will result in strong collective follower reaction, such as organizational citizenship behaviour. Organizational citizenship behaviour represents valuable pro-social actions that go above and beyond the duties expected to be part of an employee's job (Organ, 1988). These behaviours are expected to result as a part of strong collective engagement and desire to help others. In contrast, a strong egocentric influence represented by a machiavellian leaders, causes followers to reciprocate with egocentric reactions, such as negative impression management.

It must be noted that charisma and machiavellianism are not proposed to be opposites, but are clarified as the descriptors of the employee perceptions at the two ends of the value system axis. Further, this paper argues that employee perceptions are crucial, as these lead to employee actions, regardless of perception accuracy (Blancero, Johnson, \& Lakshman, 1996; McShane, 2001). This is even more intuitively appealing since, given sufficient time, and close contact with the entrepreneur, employees will have the opportunity to perceive reasonably accurately the motivations of their leader. In contrast, previous research on charisma (for example, Deluga, 2001; Tucker, 1970) has considered participants without personal knowledge of the (usually) famous individuals they were questioned about.

It is suggested in this paper that this leader-follower interaction will have a direct effect on the EO-Performance relationship of the organization. To further discuss and support the proposed framework, Figure 2 presents the first stage of the expounded context of the leaderfollower interaction, and its effect on organizational EO-Performance relationship. Realizing that the proposed framework is fairly complex, in order to enhance communication clarity, two stages are used in the development of the final framework. 


\section{INSERT: Figure 1b - A Conceptual Framework of EO-Performance Relationship}

Building on the assumption that employees have a more clear comprehension of the motives of their leader(s), Figure 2 presents the essence of the basic framework (simplified for ease of discussion). It is proposed that EO-Performance relationship is impacted by the (perceived) value system of an organization, as discussed later in this paper. Two value systems identified are Egocentric (Self-enhancing) and Organizational (Collective) value system. It is posited that Egocentric Value system (both leaders and follower based) is likely to decrease the EOPerformance relationship. On the other hand, the organizational (collective) system (both leaders and follower based) is likely to increases (or amplify) the strength of the EO-Performance relationship.

Further, present authors argue that these concepts are not tautological, as evidenced by many incidents of egocentric leadership behaviours found in the labour histories of most of the developed countries. In order to better expose these elements of the proposed framework, a more compete examination of these concepts ensues.

\section{Organizational (Collective) Value System}

As discussed previously, the EO-performance relationship is influenced by the leadership style of managers, as well as the value system found in the organization. Thus, this paper examines the value systems found in organizations through a consideration of machiavellian and charismatic leadership styles. Specifically, it is argued that charismatic leaders inspire 
identification with the company in their followers. This collective identification occurs when individuals internalize their beliefs about their organization (Pratt, 1998).

Along a similar line of reasoning, Yammarino and Bass (1991) found a match between weak situations and transformational leadership, where leaders are more able to express their disposition or tendency to be transformational when the situation is weak (characterized by weak norms, situational rules, and prior learning with respect to what might be considered appropriate behaviour). Weak situations can be found in the fluidity of an organic organizational structure, often encountered in entrepreneurial organizations.

This observation was also made by Miller (1983), who found that the flexibility of organizational structure increases the ability of an organization to be entrepreneurially oriented. The strength of an organic structure lies in its lack of routinization, and ability to respond quickly to differing situational requirements, often found in dynamic environments. However, this strength can become challenging to individuals, as it can increase the ambiguity associated with specific situation response. Correspondingly, Yukl (1999) proposed that charismatic leadership is more likely to occur in firms with organic structures, where leaders hold high position power, the environment is uncertain and crisis-oriented, and where external rewards may not be available. In other words, charismatic leadership may be most effective in smaller entrepreneurial firms which are still very fluid in their design and structure. Similarly, in his criticism of charismatic and transformational leadership theories, Yukl (1999) called for empirical research investigating transformational leadership within an entrepreneurial culture. Charismatic leadership is a good example of the collective leadership style discussed hereto, and is elaborated upon next in this section. Finally, Miller (1983) suggested that firms with organic structure are more likely to exhibit EO. This implies a link between an organization's entrepreneurial orientation and 
charismatic leadership because entrepreneurs typically operate in innovative and dynamic conditions.

Charismatic leadership. As the proposed framework entails discussion relating to charismatic leadership, a need is recognized to define the concept of a charismatic leader. A charismatic leader has been defined as one who articulates a vision, communicates high expectations and confidence in followers, assumes risk, sets a personal example of values and makes sacrifices to reach his (her) vision (Shamir et al., 1993). Some researchers have considered it a trait component of transformational leadership (Bass, 1990b) and implicit leadership theories, or theories which attempt to categorize prototypical leadership traits (that is, Offermann, Kennedy, \& Wirtz, 1994). Yukl (1999: 285) contended, "unlike traditional leadership theories, which emphasized rational processes, theories of transformational and charismatic leadership emphasize emotions and values".

Although this paper focuses upon perceptions of leader charisma, these arguments are supported by both charismatic and transformational leadership. Transformational leadership is generally considered to include elements of individualized consideration, intellectual stimulation, and inspirational motivation in addition to charisma (Bass, 1990b; Yukl, 1999). Researchers have disagreed over the relationship between transformational and charismatic leadership, but empirical research has demonstrated that charisma accounts for most of the variance in outcome variables when transformational leadership is measured (Bass, 1990b) and is a subset of transformational leadership (Yukl, 1999). Indeed, previous researchers have attempted to synthesize the transformational and charismatic literature. For example a two-part issue of the Leadership Quarterly is dedicated to the discussion of charismatic and transformational leadership (Conger \& Hunt, 1999). Although these two are not interchangeable, researchers have 
discussed transformational and charismatic leadership in the context of entrepreneurship, suggesting the presence of both in entrepreneurial activity (Baron \& Markman, 2000; Yukl, 1999). In spite of the construct's inherent ambiguity and differing views as to whether a leader must embody "extraordinary qualities", charisma is generally considered to have an element of follower identification with the leader (Yukl, 1999: 294).

A transformational leader will use his/her charisma to transform follower behaviours toward a common goal endorsed by the leader (Bass, 1990a). Our paper expands upon the charisma found in transformational leaders. As employees attribute motives to manager's actions, they accept or reject the manager's values. This promotes the acceptance of the leader's action, and stimulates the reciprocal actions of the employees. Consequently, this paper focuses upon the charismatic nature of the transformational and entrepreneurial leader.

It is reasoned that as an employee perceives his / her leader to be charismatic, the same employee is more likely to reciprocate with organizational citizenship behaviour. An organization that has employee dedication and organizational citizenship behaviour is identified as having a firm level resource (Teece, 1996), that leads to development of unique capabilities and thereafter competitive advantage (Eisenhardt \& Martin, 2000; Grant, 1991). Because small firms are perceived as more vulnerable, and have fewer employees, these employees have a broader range of responsibilities. Accordingly, leadership and employee actions are even more crucial to small developing firms and entrepreneurial organizations. Charisma explains why some leaders are considered extraordinary and others are not (Weber, 1924/1947). As charismatic leaders might arise in times of crisis, they are a function of both their traits and situation. Charismatic leaders are identified as self-confident, purposeful and able to communicate goals and ideas accepted by their followers (Bass, 1990a). 


\section{Egocentric Self-Enhancing Value System}

In contrast to the collective value system of a charismatic leader, it is suggested that a leader's egocentric, or self-enhancing value system, will create a machiavellian leadership style. This implies that the leader is primarily motivated by personal, self-serving goals, which when in conflict with organizational goals, become an overriding motivation. Whereas much of the past research deals with notable figures (Deluga, 2001; Emrich, Brower, Feldman, \& Garland, 2001), it is not applicable to this paper since many of the respondents do not have personal knowledge of the leader, but rather rely on second hand information. The principal assumption of this paper is that employees who spend much of their time in contact with the entrepreneur, will have a more intimate knowledge of the leader, and will be more able to discern between the charismatic and machiavellian motivation of the entrepreneur. Machiavellianism is a good example of the self-enhancing leadership style and is discussed next.

Machiavellian leadership. Employees are likely to see egocentric behaviour by their leader as representing machiavellian leadership. Machiavellian leadership takes its name from Nicolo Machiavelli, who described the nefarious political tactics used by Cesar Borgia to retain control over his Renaissance period Italian principality (Machiavelli, 1513/1962). Modern day theorists consider machiavellian leaders to be those who place more emphasis on getting the job done than on the emotional and moral considerations of those affected (Christie, 1970). Charismatic leaders operate within a framework of social influence, whereas machiavellian leaders use influence tactics, such as ingratiation and blocking, game playing and heresthetics (reframing of an issue) to gain greater control (for more information please see (Bass, 1990a; Kipnis, Schmidt, \& Wilkinson, 1980). 
Building upon past research, the natures of charismatic and machiavellian styles can be compared and contrasted, which may be the most effective way of expounding the theoretical concept of machiavellianism. For example, Deluga has argued that machiavellianism and charisma share similar features, such as "high levels of expressive behavioural activity, selfconfidence, emotional regulation, and the desire to influence others" (Deluga, 2001: 339). Interestingly, Bass (1990a) contended that impression management, specifically through confidence-building, manipulation of information and image-building, forms a part of the charismatic leader's behaviour. Thus, it is noted that the concepts of both charisma and machiavellianism have some elements which, superficially at least, may suggest similar foundations of influence and impression management.

Although behaviours associated with both leadership characteristics appear similar, a deeper consideration reveals difference in the values and motives behind the behaviour. For example, Turner, Barling, Epitropaki, Butcher, and Milner (2002) discovered that a leader's level of moral reasoning is positively correlated with follower perceptions of charismatic (that is, part of transformational) leadership behaviours. In contrast, machiavellian leadership is characterized by a lack of concern over conventional morality (Christie \& Geis, 1970). High machiavellian behaviours focus upon calculative tactics instead of the ultimate idealistic goal envisioned by charismatic leaders. Christie and Geis (1970) noted that individuals with high scores on the Machiavellian scale (high MACHs) feel that those with low scores (low MACHs) are naïve, not "with it" and behave unrealistically in the real world. Low MACHs, on the other hand, believe high MACHs to be immoral and lacking in compassion and faith (Christie \& Geis, 1970).

Another difference between machiavellian and charismatic leaders rests in the type of organizational culture created by such leaders. Transformational leaders use their charisma to 
inspire followers to replace personal identification with a more collective identification with the organization (Bass, 1990a). It is proposed that this collective identification and involvement induce extra-role follower behaviours as followers model the collective vision and self-sacrifice of the charismatic leader. This reciprocity is strongly rooted in theories of social exchange (Roloff, 1981) and modeling (Wood \& Bandura, 1989). However, if followers believe that leaders are manipulating them for the leader's personal gain, they will be encouraged to react in a similar, self-protective fashion using impression management tactics. The organic structure of entrepreneurial firms is more likely to induce close contact between the entrepreneur and the employees. Thus, employees may know the entrepreneur well, and discern the true motives of the entrepreneur. Based upon whether a leader's influence is perceived as machiavellian or charismatic, the employee will reciprocate differently, that is, through personal or collective identification, and this identification will prompt different types of employee behaviours.

\section{Machiavellianism and Impression Management}

As mentioned before, Machiavellianism is "a personality trait involving willingness to manipulate others for one's own purposes" (Greenberg, Baron, Sales, \& Owen, 1998: 114). Past research suggested that an individual scoring high on the machiavellian scale (a "high MACH") is more likely to be found in weak or loosely structured situations, that is, where there are few rules and regulations (Schultz, 1993, as cited in Greenberg et al., 1998). This is attributed to a high MACH's proficiency at "keeping cool" and improvising (Christie \& Geis, 1970). Christie (1970) proposed that machiavellianism becomes relevant when rewards can be influenced by the way a situation is handled, but not necessarily tied to set objectives. Such a situation may occur in an entrepreneurially oriented organization, where employees are expected to be flexible and to 
take advantage of opportunities as they arise. It can be deducted that high machiavellianism may be a concern for organizations that are attempting to become more entrepreneurially oriented.

\section{Presentation of the Framework}

To further discuss and support the proposed framework, Figure 3 presents the final development of the proposed framework of the leader-follower interaction, and its effect on organizational EO-Performance relationship. Hereafter, six propositions are presented.

\section{INSERT: FIGURE 3}

Final Stage Conceptual Framework of Leadership role on EO-Performance Relationship

Figure 3 graphically presents a conceptual framework that is the heart of this paper. This framework asserts that both leadership and follower behaviour impact (increase or decrease) amplitude of the EO-Performance relationship. Entrepreneurs are critical element in the development of Entrepreneurial Orientation, in that their leadership affects and models the individual follower behaviour within the organization. As such, any study examining entrepreneurs' leadership effectiveness will have to engage in a combined organizational level/individual aspects.

\section{Organizational (Collective) Value System and EO-Performance Relationship}

Many of today's media outlets are flooded with the stories of charismatic leaders turning around their companies. Starting with the legacy of Lee Iacocca in the early 1980s, the average 
person is faced with the "evidence" of the power of charismatic leadership. Nevertheless, a question must be asked: Is this really the case, or is it just another media fad?

Research appears to give credence (at least in part) for the above observations. Awamleh and Gardner (1999) have suggested that higher organizational performance levels yield stronger attributes of transformational leadership and effectiveness. For example, in a study of 405 employees over a three month period, Barling, Moutinho, and Kelloway (under review) discovered that participants who met their performance goals were more likely to perceive their leaders to be transformational. Other research has demonstrated the impact of transformational leadership training on follower development and training (Dvir, Eden, Avolio, \& Sharmir, 2002). This is interesting to entrepreneurial researchers because an entrepreneurial orientation often implies high performance norms in a more hostile environments (Khandwalla, 1977; Miller \& Friesen, 1978, 1982), thereby benefiting from more committed employees. Because charisma explains such a large portion of the transformational effect (Bass 1990) we propose that a firm with higher levels of charismatic leadership will enhance efforts to make the organization more entrepreneurially-oriented in striving for higher collective performance. Consequently, high employee dedication can be viewed as a resource under RBV, with the potential outcome of improved firm performance. As a result, there is strong support for the following proposition:

Proposition 1: $\quad$ The more charismatic managers are perceived to be, the stronger the relationship between entrepreneurial orientation and organizational performance.

\section{Charisma and organizational citizenship behaviour}

Based upon the arguments previously presented, employees may be more inclined to rate the individual leader of an entrepreneurially oriented firm as being a transformational or charismatic leader. It is proposed that internalization of the group's goals entails a holistic view 
of performance, and one which includes both in-role (job-related contribution) and extra-role (non-job related and voluntary contribution) behaviours. If employees replace personal identification with collective identification, then they may engage in more in-role and extra-role behaviours promoting group effectiveness (O’Reilly and Chatman, 1986).

Pratt suggested, “organizational identification occurs when an individual's beliefs about his or her organization become self-referential or self-defining" (1998, 172). Furthermore, Pratt (1998) summarized positive organizational outcomes including decision-making, prioritizing the needs of the organization, and greater control over the organization's members. Empirically, organizational identification has been found to influence critical extra-role behaviours such as organizational citizenship behaviour (O'Reilly \& Chatman, 1986). Thus, this paper proposes that a charismatic leader influences employee collective identification, which will result in higher organizational citizenship behaviour. Indeed, House (1977) defined charismatic leadership through its effects on followers, including loyalty, commitment and identification. In a small firm or early stage entrepreneurial venture, contact between the entrepreneur and the employees is much more frequent because of the organic structure involving the entrepreneur/owner in every aspect of the venture (Covin \& Slevin, 1989; Miller, 1983; Slevin \& Covin, 1990). Consequently, entrepreneurs have greater opportunity to communicate their vision and display personal sincerity regarding that vision. By being charismatic, the entrepreneur is more likely to help sell the vision to the employees thereby transforming the organizational culture. Therefore, employees are more likely to exhibit organizational citizenship behaviour. This leads us to propose:

Proposition 2: $\quad$ The more charismatic managers are perceived to be, the more employees engage in organizational citizenship behaviours. 
Although they have been researched for over 35 years, organizational citizenship behaviours have not been viewed as important to job performance until quite recently (Diefendorff, Brown, Kamin, \& Lord, in press). These "extra-role" behaviours are not directly related to the completion of job tasks, but can have an influence on overall organizational performance. Organizational citizenship behaviour falls into three categories, the first of which is obedience, involving a respect for structure. Next, loyalty, entails community service and the embodiment of community values and finally, participation, includes an interest and involvement in community self-governance (Van Dyne, Graham, \& Dienesch, 1994). As organizations strive to become entrepreneurially oriented, they also attempt to increase the different facets of EO such as innovation, proactiveness, and risk-taking (Miller, 1983). Thus, employees high in organizational citizenship behaviour may exhibit these sought-after characteristics because they believe that it is important to look beyond specific job-related duties to a more comprehensive view of their role in the company. This is very beneficial for an entrepreneurial organization in a hostile environment with a high rate of change. By having employees that go beyond "the call of duty", such an organization develops an advantage - an enhanced ability to respond quickly to outside stimuli.

Furthermore, employees demonstrating high organizational citizenship behaviour may be likely to identify with the goals and vision of the organization's management. Organizational identification has been demonstrated as a motive driving organizational citizenship behaviour (O'Reilly \& Chatman, 1986). As a result, it is posited that a company with a high organizational citizenship behaviour employee culture (set of values) strengthens performance outcomes associated with an entrepreneurially oriented organizational vision. This argument is expressed in the following proposition: 
Proposition 3: $\quad$ The more employees engage in organizational citizenship behaviours, the stronger the relationship between entrepreneurial orientation and organizational performance

\section{Egocentric (Self-Enhancing) Value System and EO-Performance Relationship}

Is business in existence only to make money, and provide a return on the investment? Although the politically correct answer is a resounding "No," in many cases actions speak louder than words. Internalizing the above question to the organization itself, one can ask if the entrepreneur does not have the right to maintain a self-serving focus in his or her own business? Aside from the ethical dilemma (which, although important, is beyond the scope of this paper), is there any evidence to suggest that a self-serving focus is less effective?

Although the previous paragraph, essentially describes a strongly machiavellian oriented approach to business, there has been limited research on the machiavellian - performance relationship. Recently, Deluga's (2001) review of presidential biographies yielded the conclusions that machiavellianism is related to charisma, and furthermore, that machiavellianism contributes to perceptions of leader performance. In this study, participants were asked to (blindly) read the biographical material and then to rate the extent to which the profiled person would agree or disagree with machiavellian thoughts. This was then correlated with accepted measures of each president's greatness. However, acceptance of these results requires faith that the student rater's view of the person accurately reflects the personal views of subject presidents. This is even more problematic because the judgments are based upon second-hand situational accounts and subject to biographer bias. Therefore, there is questionable support for Deluga's conclusions relating charisma and machiavellianism, as realistically it would be highly unusual for constituents to rate a president perceived to be lacking in moral conviction as "great". 
Instead, it is proposed that over time, machiavellian behaviours become evident to employees, and result in a corresponding self-centered organizational environment. Thus, in this article, it is posited that managerial machiavellian behaviour will erode the EO - performance relationship resulting in the following proposition:

Proposition 4: $\quad$ The more machiavellian leaders are perceived to be, the weaker the relationship between entrepreneurial orientation and organizational performance.

High MACH (highly machiavellian) leaders are more likely to be suspicious of and to ascribe higher MACH scores to their followers (Gies \& Levy, 1970). As a result, suspicion may likely to permeate the workplace, and create an atmosphere of distrust and insecurity. Impression management tactics may be viewed as important to job security in such an environment where it appears that "every man is for himself". This concern for the preservation of personal identity arises out of leader behaviours that appear to be unethical and detrimental to followers (such as those exhibited by high $\mathrm{MACH}$ leaders). Additionally, employees may concentrate on managing impressions by doing those tasks that they perceive as valued by management, that is, tasks that "look good". Impression management behaviours might include working long hours at a deliberately slower pace. Nicholson (1998) discussed how reciprocal altruism is critical to the cooperative behaviours involved in the psychological contract between employers and employees. This suggests that lack of this altruism on the manager's part will promote reciprocal deviance from the employees. In other words, if an employee observes (what the employee considers) manipulative behaviour on the part of the entrepreneur, employee is less likely to perceive his or her engagement in manipulation as inappropriate. More specifically, it is argued that manipulative leader behaviour may encourage a manipulative follower response, such as impression management. Hence, 
Proposition 5: $\quad$ The more machiavellian leaders are perceived to be, the more employees engage in impression management tactics.

Although there appears to be no research on the effects of impression management on overall organizational performance, an understanding of this organizational level relationship may be informed by knowledge of individual differences. At an individual level of analysis, researchers have studied the use of interpersonal influence tactics, originally citing eight types of tactics: assertiveness, ingratiation, rationality, sanctions, exchange, upward appeals, blocking, and coalitions (Kipnis et al., 1980). Later, Jones and Pittman (1982) incorporated Goffman's (1959) ideas on impression management and categorized other tactics as related to selfpresentation.

Influence tactics more strongly correlate with performance assessments than extrinsic success measures like salary and promotion (Higgins, Judge, \& Ferris, 2002). Supervisor focused impression management has been demonstrated to increase supervisor liking, and exchange quality (Wayne \& Ferris, 1990), often resulting in contemptible promotions and considerations. Influence tactics, including impression management, although effective when used to influence an individual target, such as a manager with legitimate power (French \& Raven, 1959), can be ineffective, and likely counterproductive with a more distant, objective entity, such as organizational level performance. Therefore, impression management tactics are unlikely to contribute to actual organizational performance.

Both organizational citizenship behaviour and impression management attempt to respond to the influence of target others, albeit with differing motives. Bolino (1999) found that impression management concerns will motivate individuals to engage in behaviours that correspond with the type of organizational citizenship behaviour preferred, valued, and noticed 
by this influential target. Organizational citizenship behaviour will not become a part of this value mix unless management has fostered a culture whereby organizational citizenship behaviour is specifically valued and rewarded. Impression management motives may negatively affect performance, and are also likely to reduce the impact of organizational citizenship behaviour on the effectiveness and performance of the organization (Bolino, 1999). This leads to the proposition:

Proposition 6: $\quad$ The more employees engage in impression management tactics, the weaker the relationship between entrepreneurial orientation and organizational performance

In essence, this paper argues that an employee who engages in negative impression management is interested primarily in the impression created, rather than the good of the company. This means that the employee will try to impress the entrepreneur, and not help the organization. This contrasts starkly with positive organizational citizenship behaviour which engages in sincere search for a resolution to organization based issues. Each action is likely to achieve the intended results, and a corresponding effect on organization's long term performance.

To summarize, this paper proposes that leader values, often expressed (or perceived) as charisma and machiavellianism, and follower characteristics such as positive organizational citizenship behaviour and negative impression management behaviours, are built upon similar bases of influence tactics. Machiavellianism and negative impression management influence other parties toward selfish and potential questionable objectives, whereas charisma and positive organizational citizenship behaviour influence other parties toward collective and idealistic goals. 
These arguments have focused upon employees who are motivated by the leader. Kelley, (1992) discussed differing motivations involved in choosing the path of followership; some become followers in order to be transformed, others become followers in order to achieve a personal vision. However, it should be noted that even followers who rely upon an internal source of inspiration, may become discouraged by a leader's use of machiavellian tactics. Such discouragement may cause the employee to become apathetic or to disconnect from the organization. Consequently, the organization is likely to accumulate employees who are comfortable with similar tactics exercised by the leader (or entrepreneur) resulting in a compound influence on organizational performance.

\section{Practical Significance}

Many leaders are successful without gaining the level of notoriety experienced by highly paid company executives, and famous political or religious figures, previously profiled in charismatic and machiavellian research (for example, Deluga, 2001; Tucker, 1970). Little is known of the local business leaders who do not reach national notoriety, even though they drive regional economies (National Governors Association, 2000).

Thus, the paper contributes by considering leader attributes, specifically machiavellianism and charisma, on a much more "everyday" and pragmatic scale. The proposed framework support the conclusion that entrepreneurs must show themselves genuine with their employees and build the leader-follower relationship. This paper also points to the realization that such a relationship is not achieved instantly but is built over time. By focusing on the significance of the leader follower relationship, this paper serves to strengthen a proper alignment between the entrepreneur, the employee and the environment. 
The discussion of the organizational value system (Ego-centric or Collective) also suggests that the leader-follower relationship is a long term investment with a corresponding development of the appropriate value system. As such, this paper provides conceptual support for appropriate evaluation of the entrepreneur's skills and abilities and the assessment of any shortfalls found.

\section{Future Research}

The proposed framework combines two levels of analysis and different fields of research in an attempt at arriving at a more holistic understanding of the entrepreneurial environment. In order to investigate these propositions, researchers must consider various methodological questions. Empirical study of a realistic framework demands a field-based approach, and one that taps the perceptions of both entrepreneurs and employees. This approach would combat issues with leniency or halo biases that might occur when employees are asked to consider both entrepreneurial orientation and the success of the organization in one instrument.

Researchers should also consider temporal influences when studying the relationship between entrepreneurial orientation and leadership behaviours. Perhaps, as the relationship progresses, manager machiavellian behaviours will become apparent to employees and stimulate matching self-enhancing values. Changes may be reflected in the development of trust relationships over time and the movement from personal identification to collective identification. Thus, it is suggested that future researchers conduct longitudinal research and control for variables, such as employment and relationship tenure.

Much research is needed to help us understand the dynamics of charisma and machiavellianism within entrepreneurial organizations. An accurate understanding of the varying 
effects of leaders' charisma and machiavellianism on their followers is needed. It has been posited that machiavellianism and charisma are differentiated respectively by self-enhancing and collective value systems. Therefore, this argument differs from other researchers who have maintained that both can exist within the same leader (Deluga, 2001). Further research is needed to assess whether these two philosophies are compatible. Perhaps variation in the relationship that each follower holds with the leader will create differences in the way that they attribute self or collective values to their leaders' behaviours.

These differing types of relationships necessitate a consideration of levels of analysis, that is, the need to account for variation at both individual and group level of analyses. The level-of-analysis issue at the fore of the leadership literature (for example, Schriesheim, Castro, \& Cogliser, 1999; Schriesheim, Castro, Zhou, \& Yammarino, 2001), can be anticipated as an issue in the growing body of literature on entrepreneurial orientation.

Entrepreneurial firms operate in a dynamic and often hostile environment and continually strive to be innovative and competitive. In order to succeed in such an environment, they must rely on strong managerial leadership and employee commitment. This emphasizes the need to examine charisma and mach leadership styles within a context of entrepreneurship and new venture development. Previous research has demonstrated that being an entrepreneurial organization in itself is insufficient to guarantee performance outcomes. Understanding the role of values in leadership in EO-Performance relationship will enable us to fill in the missing gap, allowing firms and organizations to function more judiciously in today's changing global environment. 


\section{Conclusion}

The purpose of this article has been to stimulate research and thinking about the role leadership plays in EO-performance relationship. Review of the theory and research on RBV suggests a need for a re-conceptualization of EO that considers individual level leader and follower characteristics. The proposed conceptual framework demonstrates individual factors shaping the influence of organizational EO-performance relationship. It is proposed that the EOperformance relationship will be influenced by either egocentric (self-enhancing) or collective (organizational) values of the individuals working at the organization. The Proposed Framework suggests that a charismatic leadership style (with resulting organizational citizenship behaviour by the followers) will amplify the EO-Performance relationship, while the Machivellian leadership style (with corresponding follower behaviour) will reduce the EO-Performance relationship. Further, it is asserted that a specific leadership style affects the follower response, where charismatic leadership will result in an Organizational (Collective) Value System (with organizational citizenship behaviour), and machiavellian leadership will result in Ego-centric value system (with IM). Both of these actions further amplify the overall effect of leadership style on the EO-Performance relationship. 


\section{References}

Allen, D. A., \& McCluskey, R. (1990). Structure, Policy, Services and Performance in the Business Incubator Industry. Entrepreneurship, Theory and Practice(Winter 1990), 6177.

Alvarez, S. A., \& Busenitz, L. W. (2001). The entrepreneurship of resource-based theory. Journal of Management, 27(6), 755-775.

Amit, R., \& Schoemaker, P. J. (1993). Strategic assets and organizational rent. Strategic Management Journal, 14(1), 33-47.

Avolio, B., \& Locke, E. E. (2002). Contrasting different philosophies of leader motivation. Leadership Quarterly, 13(2), 169-191.

Awamleh, R., \& Gardner, W. (1999). Perceptions of leader charisma and effectiveness: The effects of vision content, delivery and organizational performance. Leadership Quarterly, 10(3), 345-373.

Barling, J., Moutinho, S., \& Kelloway, E. (under review). Transformational leadership and group performance: The mediating role of affective commitment. Queen's University.

Barney, J. B. (1991). Firm Resources and Sustained Competitive Advantage. Journal of Management, 17(1), 99-120.

Baron, R. A., \& Markman, G. D. (2000). Beyond social capital: How social skills can enhance entrepreneurs' success. The Academy of Management Executive, 14(1), 106-116.

Bass, B. (1990a). Bass \& Stogdill's Handbook of Leadership: Theory, research, and managerial applications (3rd ed.). New York: The Free Press.

Bass, B. (1990b). Editorial: Toward a meeting of the minds. Leadership Quarterly, 1.

Becherer, R. C., \& Maurer, J. G. (1997). The moderating effect of environmental variables on the entrepreneurial and marketing orientation of entrepreneur-led firms. Entrepreneurship Theory and Practice, 22(1), 47-58.

Blancero, D., Johnson, S. A., \& Lakshman, C. (1996). Psychological Contracts and Fairness: The Effect of Violations on Customer Service Behavior. Journal of Market-Focused Management, 1(1), 49-63.

Bolino, M. (1999). Citizenship and impression management: Good soldiers or good actors? Academy of Management Review, 24(1), 82-98.

Bygrave, W., \& Minniti, M. (2000). The social dynamics of entrepreneurship. Entrepreneurship Theory and Practice, 24(3), 25-36. 
Child, J. (1972). Organization Structure and Strategies of Control - A Replication of the Aston Study. Administrative Science Quarterly, 17(2), 163.

Christie, R. (1970). Why Machiavelli? In R. Christie \& F. Geis (Eds.), Studies in machiavellianism (pp. 1-9). New York: Academic Press.

Christie, R., \& Geis, F. (1970). Studies in machiavellianism. New York: Academic Press.

Conger, J. A., \& Hunt, J. (1999). Overview Charismatic and Transformational Leadership: Taking Stock of the Present and Future (Part 1). Leadership Quarterly, 10(2), 121-127.

Covin, J. G., \& Slevin, D. P. (1986). The development and testing of an organization-level entrepreneurship scale. Frontiers of Entrepreneurship Research.

Covin, J. G., \& Slevin, D. P. (1989). Strategic Management of Small Firms in Hostile and Benign Environments. Strategic Management Journal, 10(1), 75-88.

Cyert, R. M., \& March, J. G. (1963, 1992). A behavioral theory of the firm (Second ed.). Cambridge, Mass: Blackwell Publishers.

Deluga, R. (2001). American presidential machiavellianism: Implications for charismatic leadership and rated performance. Leadership Quarterly, 12, 339-363.

Diefendorff, J., Brown, D., Kamin, A., \& Lord, R. (in press). Examining the roles of job involvement and work centrality in predicting organizational citizenship behaviors and job performance.

Dvir, T., Eden, D., Avolio, B., \& Sharmir, B. (2002). Impact of transformational leadership on follower development and performance: A field experiment. Academy of Management Journal, 45(4), 735-744.

Eisenhardt, K. M., \& Martin, J. A. (2000). Dynamic capabilities: What are they? Strategic Management Journal, 21(10-11), 1105-1121.

Emrich, C. G., Brower, H. H., Feldman, J. M., \& Garland, H. (2001). Images in words: Presidential rhetoric, charisma, and greatness. Administrative Science Quarterly, 46(3), 527.

Feeser, H. R., \& Willard, G. E. (1989). Incubators and Performance: A Comparison of High- and Low-Growth High-Tech Firms. Journal of Business Venturing, 4(6), 429-442.

French, J., \& Raven, B. (1959). The bases of social power. In D. Cartwright (Ed.), Studies in social power. Ann Arbor: University of Michigan, Institute for Social Research. 
Gies, F., \& Levy, M. (1970). The eye of the beholder. In R. Christie \& F. Geis (Eds.), Studies in machiavellianism. New York: Academic Press.

Grant, R. M. (1991). The Resource-Based Theory of Competitive Advantage: Implications for Strategy Formulation. California Management Review, 33(3), 114-136.

Greenberg, J., Baron, R., Sales, C., \& Owen, F. (1998). Behavior in Organizations (2nd Canadian Edition ed.). Scarborough, ON: Prentice Hall Canada.

Guth, W. D., \& Ginsberg, A. (1990). Guest editor's introduction: Corporate entrepreneurship. Strategic Management Journal, 11(Special Issue), 5-15.

Hansen, G. S., \& Wernerfelt, B. (1989). Determinants of Firm Performance: The Relative Importance of Economic and Organizational Factors. Strategic Management Journal, $10(5), 399-412$.

Higgins, C., Judge, T., \& Ferris, G. (2002). Influence tactics and work outcomes: A metaanalysis. Paper presented at the Society for Industrial and Organizational Psychology, Toronto, Canada.

House, R. (1977). A 1976 theory of charismatic leadership. In J. Hunt \& L. Larson (Eds.), Leadership: The cutting edge. Carbondale: Southern Illinois University Press.

Itami, H., \& Roehl, W. T. (1987). Mobilizing Invisible Assets. Cambridge, Massachusetts: Harvard University Press.

Jones, E., \& Pittman, T. (1982). Toward a general theory of strategic self-presentation. In J. Suls (Ed.), Psychological perspectives on the self (pp. 43-66). Hillsdale, NJ: Lawrence Erlbaum.

Kelley, R. E. (1992). The power of followership: How to create leaders people want. New York: Doubleday.

Khandwalla, P. N. (1977). The Design of Organizations. New York, New York: Harcourt Brace Jovanovich, Inc.

Kipnis, D., Schmidt, S. M., \& Wilkinson, I. (1980). Intraorganizational influence tactics: Explorations in getting one's way. Journal of Applied Psychology, 65, 440-452.

Lee, C., Lee, K., \& Pennings, J. M. (2001). Internal capabilities, external networks, and performance: A study on technology-based ventures. Strategic Management Journal, $22(6 / 7), 615-640$.

Lumpkin, G. T., \& Dess, G. G. (1996). Clarifying the entrepreneurial orientation construct and linking it to performance. Academy of Management, 21(1), 135-173. 
Lumpkin, G. T., \& Dess, G. G. (2001). Linking two dimensions of entrepreneurial orientation to firm performance: The moderating role of environment and industry life cycle. Journal of Business Venturing, 16(5), 429-451.

Machiavelli, N. (1513/1962). The Prince. New York: Mentor Press.

McShane, S. L. (2001). Canadian Organizational Behaviour (Fourth Edition ed.). Toronto: McGraw-Hill Ryerson Limited.

Miles, R. E., \& Snow, C. C. (1978). Organizational Strategy, Structure, and Process. Toronto: McGraw-Hill Book Company.

Miller, D. (1983). The Correlates of Entrepreneurship in Three Types of Firms. Management Science, 29(7), 770-792.

Miller, D., \& Friesen, P. H. (1978). Archetypes of Strategy Formulation. Management Science, 24(9), 921.

Miller, D., \& Friesen, P. H. (1982). Innovation in Conservative and Entrepreneurial Firms: Two Models of Strategic Momentum. Strategic Management Journal, 3(1), 1-25.

Mintzberg, H. (1973). The Nature of Managerial Work. New York: Harper \& Row.

Morris, M. H., \& Paul, G. W. (1987). The Relationship Between Entrepreneurship and Marketing in Established Firms. Journal of Business Venturing, 2(3), 247-260.

Naman, J. L., \& Slevin, D. P. (1993). Entrepreneurship and the concept of fit: A model and empiric. Strategic Management Journal, 14(2), 137-154.

National Governors Association. (2000). Nurturing Entrepreneurial Growth in State Economies. Washington, D.C.: National Governors Association.

Nelson, R. R. (1991). Why Do Firms Differ, and How Does It Matter? Strategic Management Journal, 12, 61-75.

Nicholson, N. (1998). Seven deadly syndromes of management and organization: The view from evolutionary psychology. Managerial and Decision Economics, 19, 411-426.

Offermann, L., Kennedy, J., \& Wirtz, P. (1994). Implicit leadership theories: Content, structure and generalizability. Leadership Quarterly, 5(1), 43-58.

O'Reilly, C., \& Chatman, J. (1986). Organizational commitment and psychological attachment: The effect of compliance, identification, and internalization on prosocial behavior. Journal of Applied Psychology, 71(3), 492-499. 
Organ, D. W. (1988). Organizational citizenship behaviour: The good soldier syndrome. Lexington, MA: Lexington Books.

Penrose, E. T. (1959). The theory of the growth of the firm. New York: John Wiley and Sons.

Peteraf, M. A. (1994). The cornerstones of competitive advantage: A resource-based. Strategic Management Journal, 14(3), 179-192.

Pratt, M. (1998). To be or not to be: Central questions in organizational identification. In D. Whetton \& P. Godfrey (Eds.), Identity in organization, building theory through conversations (pp. 171-208). Thousand Oaks: Sage Publications.

Reid, G. C., \& Smith, J. A. (2000). What makes a new business start-up successful? Small Business Economics, 14(3), 165-182.

Roloff, M. E. (1981). Interpersonal Communication: The social exchange approach. Newbury Park, CA: Sage.

Schriesheim, C. A., Castro, S. L., \& Cogliser, C. C. (1999). Leader-Member Exchange (LMX) Research: A comprehensive review of theory, measurement and data-analytic practices. Leadership Quarterly, 10(1), 63-113.

Schriesheim, C. A., Castro, S. L., Zhou, X. T., \& Yammarino, F. (2001). The folly of theorizing "A"but testing "B": A selective level-of-analysis review of the field and a detailed Leader-Member Exchange illustration. Leadership Quarterly, 12, 515-551.

Schumpeter, J. A. (1934). The theory of Economic Development (O. R., Trans. 7th ed.). Cambridge, MA: Harvard University Press.

Shamir, B., House, R., \& Arthur, M. B. (1993). The Motivation Effects of Charismatic Leadership. A Self-concept Based Theory. Organization Science, 4, 584.

Slevin, D. P., \& Covin, J. G. (1990). Juggling Entrepreneurial Style and Organizational Structure. Sloan Management Review, 31(2), 43-54.

Smart, D. T., \& Conant, J. S. (1994). Entrepreneurial orientation, distinctive marketing competencies and organizational performance. Journal of Applied Business Research, 10(3), 28-39.

Teece, D. J. (1996). Firm organization, industrial structure, and technological innovation. Journal of Economic Behavior \& Organization, 31(2), 193-224.

Teece, D. J., Pisano, G., \& Shuen, A. (1997). Dynamic capabilities and strategic management. Strategic Management Journal, 18(7), 509-533. 
Tucker, R. (1970). The theory of charismatic leadership. In D. Rustow (Ed.), Philosophers and kings: Studies in leadership. New York: Braziller.

Turner, N., Barling, J., Epitropaki, O., Butcher, V., \& Milner, C. (2002). Transformational leadership and moral reasoning. Journal of Applied Psychology, 87(2), 304-311.

Van Dyne, L., Graham, J., \& Dienesch, R. (1994). Organizational citizenship behavior: Construct redefinition, measurement, and validation. Academy of Management Journal, 37(4), 765-802.

Wayne, S., \& Ferris, G. (1990). Influence tactics, affect, and exchange quality in supervisorsubordinate interactions: A laboratory experiment and field study. Journal of Applied Psychology, 75, 487-499.

Weber, M. (1924/1947). The theory of social and economic organization (T. Parsons, Trans.). New York: Free Press.

Wernerfelt, B. (1984). The Resource-based View of the Firm. Strategic Management Journal, 5(2), 171-181.

Wiklund, J. (1999). The sustainability of the entrepreneurial orientation--performance relationship. Entrepreneurship Theory and Practice, 24(1), 37-48.

Williamson, O. E. (1999). Strategy research: Governance and competence perspectives. Strategic Management Journal, 20(12), 1087-1108.

Wood, R., \& Bandura, A. (1989). Social cognitive theory of organizational management. Academy of Management Review, 14(3), 361-384.

Yammarino, F., \& Bass, B. (1991). Person and situation views of leadership: A multiple level of analysis approach. Leadership Quarterly, 2(21), 121-129.

Yukl, G. (1999). An evaluation of conceptual weaknesses in transformational and charismatic leadership theories. Leadership Quarterly, 10(2), 285-305.

Zahra, S. A. (1991). Predictors and Financial Outcomes of Corporate Entrepreneurship: An Exploratory Study. Journal of Business Venturing, 6(4), 259-286.

Zahra, S. A. (1993). Environment, corporate entrepreneurship, and financial performance: A taxonomic approach. Journal of Business Venturing, 8(4), 319-341.

Zahra, S. A., Covin, J. G., \& Slevin, D. P. (1995). Contextual influences on the corporate entrepreneurship-performance relationship: A longitudinal analysis. Journal of Business Venturing, 10(1), 43-59. 
FIGURE TO BE INSERTED INTO THE MANUSCRIPT

\section{FIGURE 1}

A Conceptual Framework of Leader - Follower Relationship

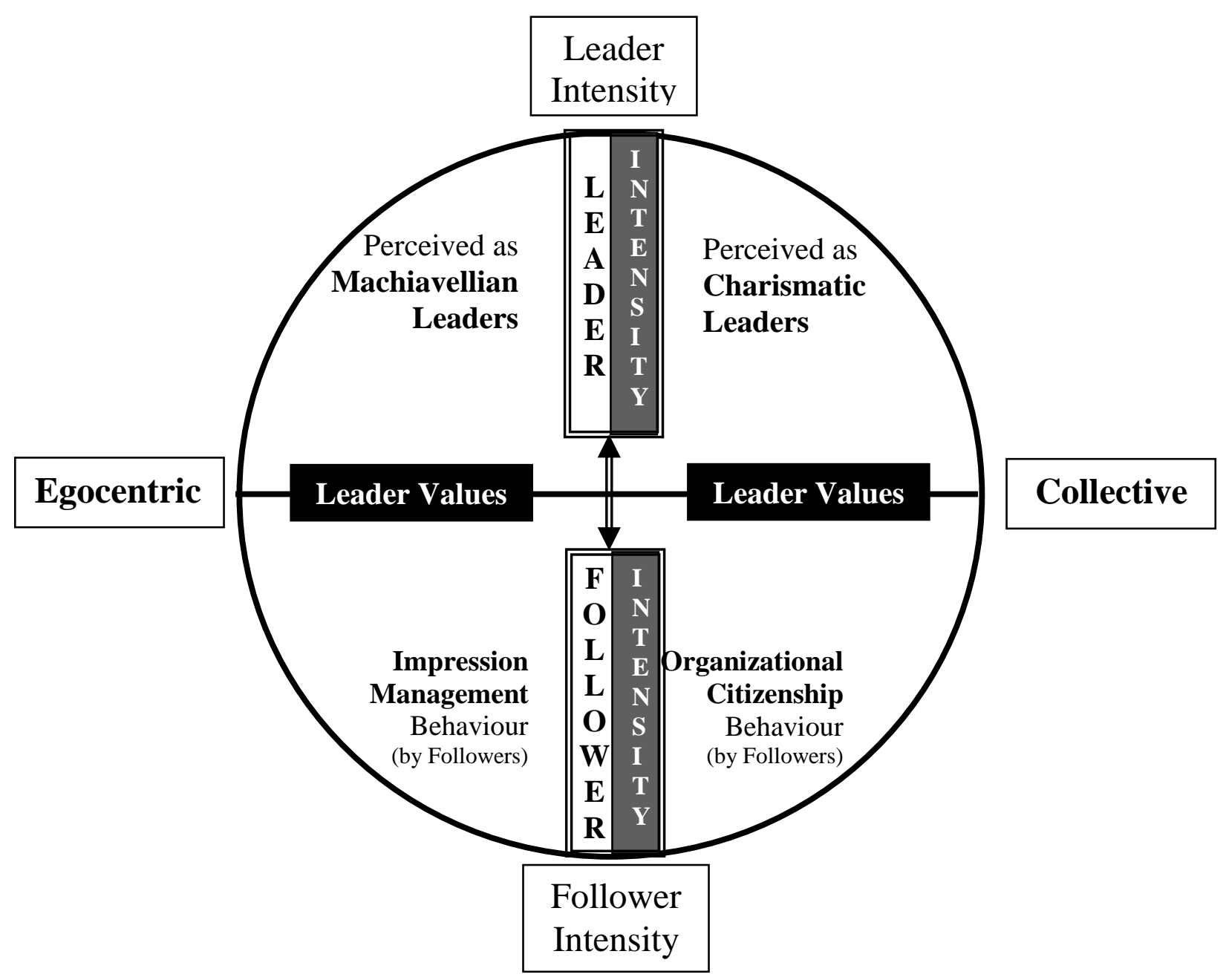


Figure 2 - A Conceptual Framework of EO-Performance Relationship

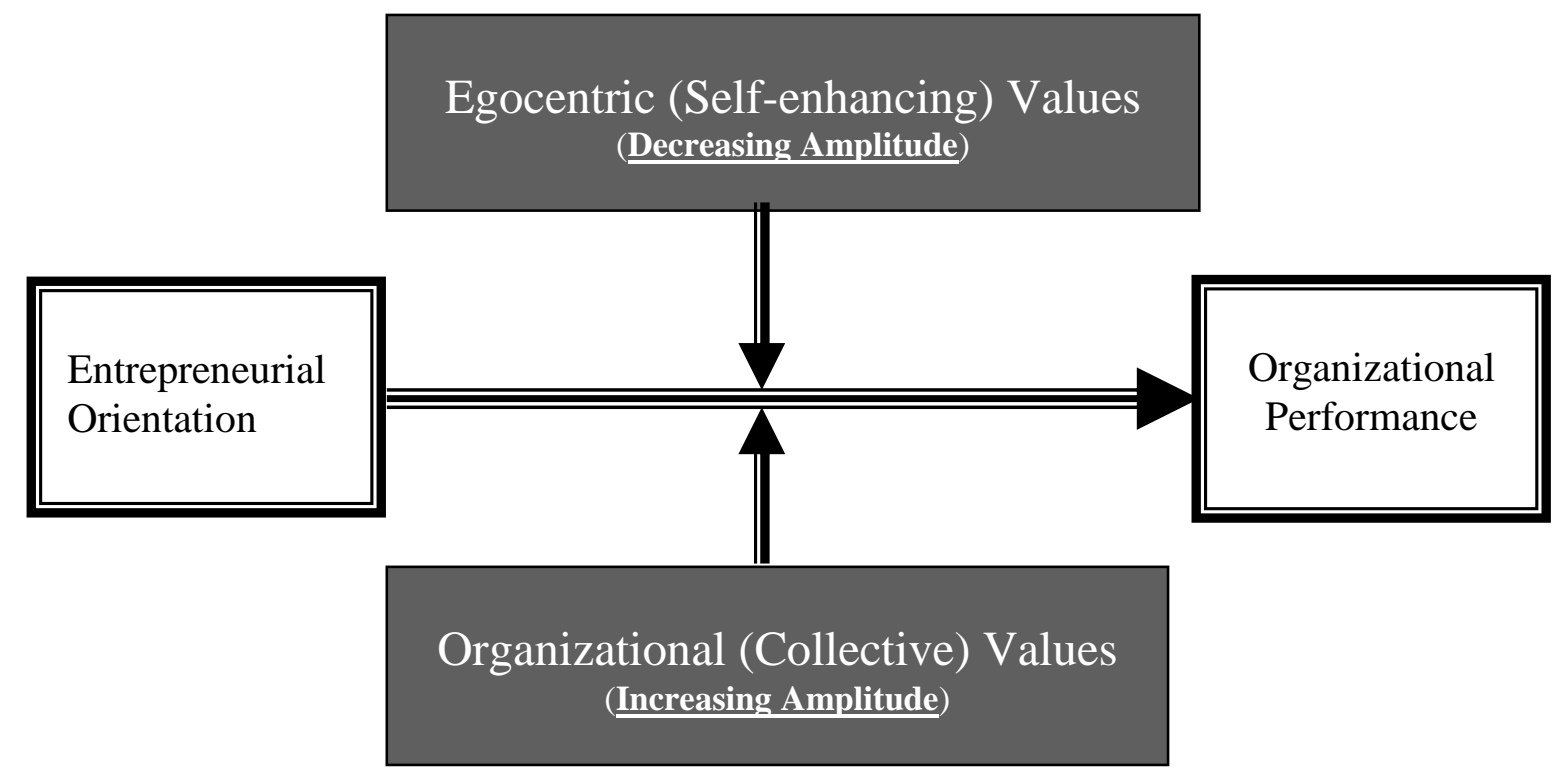


FIGURE 3

Final Stage Conceptual Framework of Leadership role on EO-Performance

Relationship

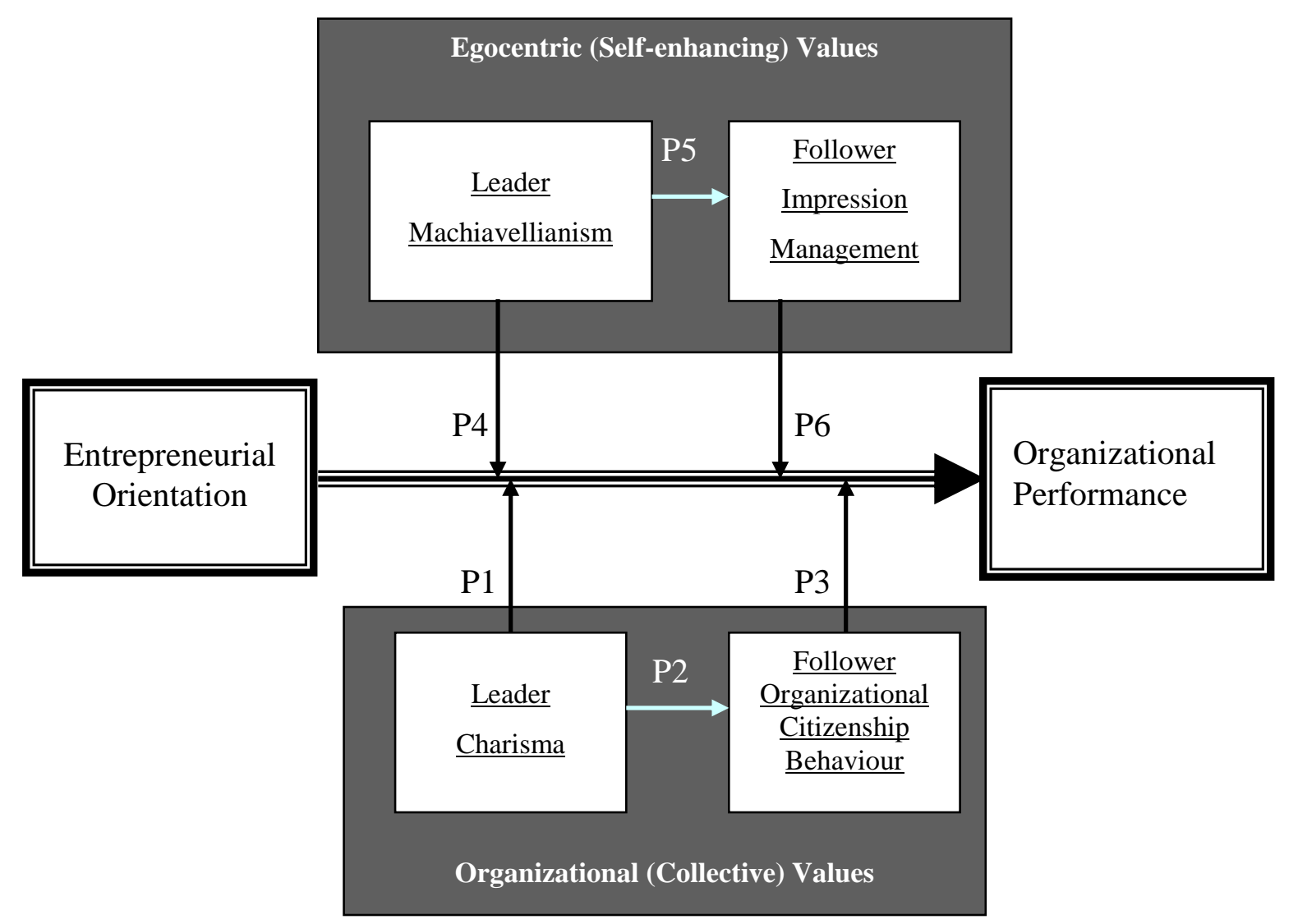

